Article

\title{
Energy Evaluation and Greenhouse Gas Emissions of Reed Plant Pelletizing and Utilization as Solid Biofuel
}

\author{
Algirdas Jasinskas *, Dionizas Streikus, Egidijus Šarauskis@, Mečys Palšauskas and \\ Kęstutis Venslauskas (D) \\ Institute of Agricultural Engineering and Safety, Vytautas Magnus University, Agriculture Academy, \\ Studentu 15 B, Akademija, LT-53362 Kaunas, Lithuania; streikusdionizas@gmail.com (D.S.); \\ egidijus.sarauskis@vdu.lt (E.Š.); mecys.palsauskas@vdu.lt (M.P.); kestutis.venslauskas@vdu.lt (K.V.) \\ * Correspondence: algirdas.jasinskas@vdu.lt; Tel.: +370-612-04002
}

Received: 14 January 2020; Accepted: 18 March 2020; Published: 23 March 2020

check for updates

\begin{abstract}
This paper presents the results of research on the preparation and use for energy purposes of three reed herbaceous energy plants: reed (Phragmites australis) and bulrush (Typha); both grown in local vicinities on lakes and riverbanks and reed canary grass (Phalaris arundinacea L.). The physical-mechanical characteristics (density, moisture, and ash content) of chopped and milled reeds were investigated. The investigation of mill fractional compositions determined the largest amount of mill—reed mill, collected on the sieves of $0.63 \mathrm{~mm}(40.0 \%)$. The pellet moisture ranged from $10.79 \%$ to $6.32 \%$, while the density was $1178.9 \mathrm{~kg} \mathrm{~m}^{-3}$ for dry matter (DM) of reed. The ash content of reed, bulrush and reed canary grass pellets was $3.17 \%, 5.88 \%$, and $7.99 \%$, respectively. The ash melting temperature ranged from 865 to $1411^{\circ} \mathrm{C}$; these temperatures were high enough for ash melting. The determined pellet calorific value varied from 17.4 to $17.9 \mathrm{MJ} \mathrm{kg}^{-1} \mathrm{DM}$. The disintegration force, indicating pellet strength, ranged from $324.25 \mathrm{~N}$ for reed canary grass to $549.24 \mathrm{~N}$ for reed. The determined emissions of harmful pollutants- $\mathrm{CO}_{2}, \mathrm{CO}, \mathrm{NO}_{\mathrm{x}}$, and unburnt hydrocarbons $\left(\mathrm{C}_{\mathrm{x}} \mathrm{H}_{\mathrm{y}}\right)-\mathrm{did}$ not exceed the maximum permissible levels. The assessment of greenhouse gas emissions (GHG) from technology showed that the $\mathrm{CO}_{2}$ equivalents ranged from 7.3 to $10.1 \mathrm{~kg} \mathrm{CO}_{2}$-eq. $\mathrm{GJ}^{-1}$ for reed and reed canary grass, respectively.
\end{abstract}

Keywords: solid biofuel; pellet and ash properties; emissions; energy evaluation; greenhouse gas

\section{Introduction}

Plant biomass is globally recognized and used as an alternative source of renewable energy, which should gradually replace the still most popular fossil fuel that accounts for approx. $86 \%$ of the total energy consumption [1,2]. Increasing the use of biomass and biofuels will contribute to reducing the greenhouse effect $[3,4]$. The depletion of fossil fuel, together with its increasing costs and adverse environmental impact, has led researchers to look for alternative renewable energy sources [5]. The increasing costs of fossil fuels are due to its excessive use, high market demand, and the gradual reduction of the use of fossil fuel technologies causing climate changes [5].

However, some countries have problems with cultivated land areas and their use. For example, in Italy, the plantations of high-density energy crops have been widespread since the 1990s, but there has been a change in trend because this method significantly damaged the cultivated land quality [6].

The energy sector is also important for Baltic Sea Region countries, such as Lithuania, Latvia, and Estonia. Here, fossil fuel resources are very limited; therefore, it is necessary to look for alternative fuels and thus increase the country's energy independence. Biofuels are in high demand in Lithuania and are an important alternative source of renewable energy: raw material produced from biomass waste. The most well-known and widespread biofuel in Lithuania and other countries is wood biomass 
fuel; however, a rising need to save wood resources is forcing the search for alternatives. One suitable wood substitute could be reed. Some results from a reed caloric value research proved that reed could be similar to pine and spruce: the calorific value of dry matter of reed reached $18.7 \mathrm{MJ} \mathrm{kg}^{-1}[3,7]$. According to the standards, the moisture content is 10\%-12\% [8]. Another research showed that dry reed could be a precious fuel: it is burnable and its calorific value exceeds that of straw and is almost equal to the calorific value of wood waste (dry reed calorific value- $-17.9 \mathrm{MJ} \mathrm{kg}^{-1}$, wheat and barley straw calorific value-16.5 MJ kg-1, birch wood calorific value-18.2 $\mathrm{MJ} \mathrm{kg}^{-1}$ ) [9]. This topic is not new but is very relevant for Lithuania and other European countries with similar climatic conditions because it is necessary to realize the resources that are possible and determine which can be best used for fuel production. To investigate the use of reeds for biofuel and their suitability for energy conversion, it is necessary to do comprehensive research investigations [10].

The atmospheric carbon dioxide $\left(\mathrm{CO}_{2}\right)$ concentration has been constantly rising. For example, it was around $270 \mathrm{ppm}$ in the pre-industrial period and has recently reached more than $400 \mathrm{ppm}$. According to these trends, due to the combustion of fossil fuels and keeping in mind the planned changes in fuel usage, it is expected that, by 2030, the concentration will increase to $450 \mathrm{ppm}[11,12]$.

Plant biofuels, such as wood, straw, and energy crops, have been widely used in Europe and Lithuania. These products form a significant part of the local fuel [13].

Various vegetable biomass feedstocks have been increasingly used in energy conversion technologies; they have increased a variety of produced biofuels and the amount of agricultural land used for energy plant growing [13].

In 2018, renewable energy accounted for $18 \%$ of the energy consumed in the European Union (EU) [14] and for $25.03 \%$ in Lithuania [15]. The EU imports about $48 \%$ of its energy from Russia and Norway. Based on the EU Sustainable Development Strategy, by 2020, the use of solid biofuels should increase heat production to $67 \%$ of the overall energy balance [16].

The biomass fuel potential of straw in Lithuania is equivalent to 850 thousand tons of oil (toe), that of municipal waste is 200 thousand toe, and that of wood is 1033 thousand toe [17].

In Europe, the demand for biomass to be converted into heat by combustion is likely to increase as well [18]. Plant biomass is widely used in alternative energy [19]. With the rise in oil prices and mitigation of ever-increasing climate change, the production and use of solid biofuels are increasingly focused on the granulated biofuels that are becoming popular in European countries [20,21]. Various types of processed plant biomasses can be used as biofuels for sufficient effective combustion and heat production: firewood, wood chips, straw bales, and briquettes [22-27]. However, pellet and pressed residue burning are the most efficient ways to utilize various sorts of biomass for the production of energy and heat [28]. The pellet burning process can be fully automated; it can be set for a certain period and it automatically maintains and controls the quality and efficiency of pellet combustion based on ambient or indoor temperature parameters.

For the evaluation of biofuel raw materials suitability for energy conversion processes, it is important to determine the basic composition of raw material chemical elements $(C, H, N, O, S)$ [29-31]. Biofuel combustion causes a carbon-oxygen reaction and produces water and carbon dioxide [32].

Fixed carbon is important in assessing the quality of biofuels: the higher the value, the higher the energy content of the biofuel [33].

To increasingly replace fossil fuels with indigenous resources, it is advisable to produce energy from a wide range of crops from agriculture and forests and organic residues from their processing [34-38].

The quality of biofuels is also reflected in its combustion products-ash, the amount of useful and harmful chemical elements in it, and the formation of slag in ash (ash melting) —which have a major impact on the operation of incinerators. These ash properties are highly dependent on the type, origin, and impurities of the burned biofuel. Research results of woody plant ash melting studies showed that ash melting temperature of widely used forest lignocellulosic biomass of deciduous and coniferous forests varied from 1250 to $1650{ }^{\circ} \mathrm{C}$ [39]. The ash melting is strongly influenced by the 
chemical elements and mineral composition of the ash and it is important to control and maintain the proper combustion regime of the biofuel [39].

In summary, this work aimed to investigate and determine the most important properties of reed plants that influence their preparation and use for energy conversion.

Many researchers have studied, analyzed, and compared various types of biofuels, but they investigated only their individual properties, whereas, for biofuel production and burning, they used a variety of different pressing and burning implements every time. The research presented here has been performed and the results presented in a complex manner, using certified measuring devices and combustion equipment, uniform for all plants. The relationship between different properties and the results of their comparative evaluations have been examined; additionally, the theoretical dependencies of pellet qualitative indices and the greenhouse gas (GHG) emission analysis have been developed and presented, thus creating the novelty of this study.

\section{Materials and Methods}

\subsection{Reed Plant Characteristics, Plant Chopping, and Milling}

Reed (Phragmitesaustralis) is a plant of the herbaceous plant family. It grows in wetlands, on river and lake banks, in swamps, and in road trenches and reaches $100-400 \mathrm{~cm}$ tall. Very important reed plantations in Lithuania grow on the shores of the Curonian Bay. Young plants are high in protein and sugar, making them liked by cattle. However, as they grow rapidly, the nutrition of these plants drops dramatically, and they become very hard and not appealing to animals [40].

Bulrush (Typha) is a cattail (Typhaceae) family plant. It has a creeping thick rhizome and is high in starch. Flowers are concentrated in the ears. It has two kinds of roots: one long, to help the plant anchor to the soil, and one short, to soak up water. These plants grow in swamps and on slow running water banks up to $1.5 \mathrm{~m}$ deep. The starch-rich rhizomes are used for food and human medicine [41].

Reed canary grass (Typhoidesarundinocea L.) is a tall $(180-200 \mathrm{~cm}$ ) perennial grass plant with wide leaves and long rhizomes. Its truss is a thick besom, in which ears are focused on small balls. The bottom besom grate makes two besoms. The seeds are small and lightweight (2000 pieces- $1 \mathrm{~g}$ ) and bright grizzly brown in color [42].

To produce pressed biofuel, the above reed plants were chopped with a Maral125 forage harvester drum chopper (Fortschritt, Germany). During the production of pellets, the plants were chopped by a drum chopper and milled by a Retsch SM 200 hammer mill (Retsch, Germany). The fractional composition of the mill was determined by weighing the mass accumulated on the sieves. The sieves with different holes, $0.25,0.5,0.63,1.0$, and $2.0 \mathrm{~mm}$, were used [43]. Each test was repeated five times.

\subsection{Pellet Production and Investigation of Their Properties}

The milled reed plants were granulated with a $7.5 \mathrm{~kW}$ pelletizer (Polexim, Poland) with a horizontal pellet production matrix with $6 \mathrm{~mm}$ holes. The pellet production productivity of the granulator was 250-350 kg h${ }^{-1}$. The main characteristics of the presented machines and measuring equipment are presented in references [44,45].

The lower calorific value, $\mathrm{LHV}\left(\mathrm{KJ} \mathrm{kg}^{-1}\right)$, elemental composition, ash, and moisture contents (\%) of reed plant pellets were determined at the Lithuanian Energy Institute using special equipment, testing laboratories, and devices. These studies were conducted following the valid standard methodologies of Lithuania and other European Union countries [19,39,46].

The mechanical compressive strength of the pellets was investigated using an "Instron Universal Tester" (USA). Cylindrical pellets $(6.0 \pm 0.3 \mathrm{~mm}$ in diameter and $20 \pm 0.5 \mathrm{~mm}$ in length) were placed horizontally on a plate and exposed vertically with an $8.0 \mathrm{~mm}$ diameter rod until the pellet was broken. The measurement data were recorded on a computer with a special program [39].

The ash melting characteristics were investigated by using ash from burned reed plant pellets, forming cylinders of defined dimensions, heating them in a high-temperature digital oven Carbolite 
$\mathrm{CAF}$, and recording the dynamics of the samples. Ash melting temperatures were tested according to the requirements of LST CEN/TS 15370-1: 2007 and the methodology approved by the Lithuanian Energy Institute [39].

\subsection{Determination of Harmful Emissions}

In order to evaluate the emission of harmful gases into the environment from the burning of various reed plant pellets, the produced pellets were burned in a low-capacity pellet fuel boiler in the laboratory of the Lithuanian Energy Institute. Samples of pellets of different plants ( $5 \mathrm{~kg}$ each) were burned for 15-20 min; harmful gases emitted during combustion were recorded with a DATATEST 400 CEM smoke analyzer [39].

\subsection{Evaluation of Energy and GHG Emissions of Technology}

Energy evaluation of technology.

For energy evaluation of reed plant biofuel preparation and utilization technology, the technological operations were justified and proposed, and the best technique was selected. The following technological operations for pellet preparation and burning were selected, and energy consumption for preparation and use for the burning of the granulated biofuel was calculated:

- Total energy consumption of reed harvesting, loading onto vehicle trailers, and transporting to storage facilities;

- Plant chopping, milling, and drying, in order to reduce moisture content by $10 \%$;

- Biomass pellet production in low power granulator;

- Produced pellet transportation and combustion in the boiler.

Determination of reed plant harvesting and granulated biofuel production energy indicators were carried out according to the standard methodology [7,45].

GHG emissions.

The environmental performance of each of the examined scenarios was compared at the midpoint level using the IMPACT 2002+ impact method [47]. At the midpoint, the global warming potential (GWP) of the impact category over 100 years, expressed in $\mathrm{CO}_{2}$ equivalents, was used.

The biomass granulation technologies based on an energy-based functional unit were compared. The functional unit was " 1 GJ of lower heating value". Likewise, the industrial biomass energy (granulation) technology lines, transportation, and energy user descriptions generally refer to $1 \mathrm{MJ}$ or $1 \mathrm{GJ}$ as a reference flow.

To assess the impact on the environment of reed plant pellet preparation for heat energy generation and use, the analysis has relied upon the assessment of the GHG emissions. The software SimaPro 8.0.5 was used to assess GHG emissions [48].

Inputs for calculation of the GHG emissions of reed processing into pellets included following technologies: stem cutting and shredding, transportation of crushed stems, stack cutting of stems in storage place, milling with $75 \mathrm{~kW}$ mill and capacity of $4000 \mathrm{~kg} \mathrm{~h}^{-1}$, and granulation with $11 \mathrm{~kW}$ pelletizer and capacity of $120 \mathrm{~kg} \mathrm{~h}^{-1}$. The emissions of electric power consumption as an average European electricity mix [49].

\section{Results and Discussion}

\subsection{Plant Mill Fractional Composition}

The research results of the authors of different reed plant yields showed that the yield of bulrush was very low and reached $2.3 \mathrm{tha}^{-1} \mathrm{DM}$ (dry matter), while the yields of reed and reed canary grass were four times higher: 8.2 and $10.0 \mathrm{tha}^{-1} \mathrm{DM}$.

The mill fractional composition greatly influences pellet quality indicators, such as density and resistance to compression. Additionally, when granules are produced from reeds of different thickness, 
the moisture content may differ as well. The fractional composition of reed plants has been determined and the results provided in Table 1.

Table 1. Fractional composition of reed plant mills.

\begin{tabular}{lcccccc}
\hline \multirow{2}{*}{$\begin{array}{c}\text { Plant } \\
\text { Species }\end{array}$} & \multicolumn{5}{c}{$\begin{array}{c}\text { Average Fraction Remaining on a Sieve with Error, } \% \\
\text { (Diameter of Sieve Holes, mm) }\end{array}$} \\
\cline { 2 - 7 } & $\mathbf{2 . 0}$ & $\mathbf{1 . 0}$ & $\mathbf{0 . 6 3}$ & $\mathbf{0 . 5}$ & $\mathbf{0 . 2 5}$ & $\mathbf{0}$ \\
\hline Reed & $0.70 \pm 0.60$ & $8.70 \pm 4.65$ & $40.00 \pm 7.35$ & $4.00 \pm 0.10$ & $32.00 \pm 0.22$ & $14.70 \pm 4.25$ \\
$\begin{array}{l}\text { Bulrush } \\
\text { Reed canary }\end{array}$ & $0.01 \pm 0.01$ & $3.87 \pm 0.99$ & $29.50 \pm 2.45$ & $22.74 \pm 3.40$ & $23.45 \pm 1.97$ & $20.38 \pm 2.61$ \\
grass & $1.00 \pm 0.10$ & $28.30 \pm 4.20$ & $12.30 \pm 2.80$ & $20.20 \pm 1.10$ & $24.80 \pm 2.40$ & $13.40 \pm 1.20$ \\
\hline
\end{tabular}

Research on the biometrical properties of reed, bulrush, and reed canary grass pellets showed that the moisture content of bulrush pellets was the highest, $14.16 \pm 2.02 \%$, and, if compared to reed and reed canary grass pellets, it was twice as low, $6.23 \pm 5.12 \%$ and $6.73 \pm 0.07 \%$, respectively.

\subsection{Pellet Density and Elemental Composition}

The pellet density of the reed plants was analyzed and proven to be sufficiently high (the density was higher than $1000 \mathrm{~kg} \mathrm{~m}^{-3} \mathrm{DM}$ ) when it reached the following numbers: for reed, $1178.9 \mathrm{~kg} \mathrm{~m}^{-3} \mathrm{DM}$ (dry matter); for bulrush, $1050.0 \mathrm{~kg} \mathrm{~m}^{-3} \mathrm{DM}$; and for reed canary grass, $1035.1 \mathrm{~kg} \mathrm{~m}^{-3} \mathrm{DM}$.

The determined pellet physical-mechanical and other properties are presented in Table 2. According to our investigation, bulrush and reed canary grass pellets contained three main components: carbon $(\mathrm{C})$, hydrogen $(\mathrm{H})$, and oxygen $(\mathrm{O})$, which together made up $93 \%$ (in bulrush) and $81 \%$ (in reed canary grass). The basic elemental compositions of reed, bulrush, and reed canary grass consisted of carbon $(\mathrm{C})$ and oxygen $(\mathrm{O})$, and a third different element, nitrogen $(\mathrm{N})$, which was found in reed pellets $(5.56 \%)$.

Table 2. Elemental composition and physical-mechanical properties of reed plants.

\begin{tabular}{|c|c|c|c|c|c|c|c|c|}
\hline \multirow{2}{*}{$\begin{array}{l}\text { Type of } \\
\text { Biofuel }\end{array}$} & \multicolumn{5}{|c|}{ Elemental Composition \% } & \multirow{2}{*}{$\begin{array}{c}\text { Moisture } \\
\text { Content \% }\end{array}$} & \multirow{2}{*}{$\begin{array}{c}\text { Ash } \\
\text { Content \% }\end{array}$} & \multirow{2}{*}{$\begin{array}{c}\text { Calorific } \\
\text { Value } \mathrm{MJ} \mathrm{kg}^{-1}\end{array}$} \\
\hline & $\mathrm{C}$ & $\mathrm{O}$ & $\mathbf{H}$ & S & $\mathbf{N}$ & & & \\
\hline Bulrush & $47.50 \pm 0.35$ & 39.85 & $5.67 \pm 0.39$ & $0.01 \pm 0.01$ & $1.10 \pm 0.35$ & $10.79 \pm 0.07$ & $5.88 \pm 0.06$ & $17.47 \pm 0.43$ \\
\hline Reed & $48.48 \pm 1.16$ & 42.25 & $0.44 \pm 0.32$ & $\begin{array}{c}0.05 \pm \\
23.13\end{array}$ & $5.56 \pm 0.45$ & $6.32 \pm 0.02$ & $3.17 \pm 0.13$ & $17.86 \pm 0.31$ \\
\hline $\begin{array}{l}\text { Reed } \\
\text { canary } \\
\text { grass }\end{array}$ & $45.47 \pm 1.13$ & 30.40 & $5.70 \pm 0.44$ & $0.19 \pm 0.27$ & $1.19 \pm 0.37$ & $6.73 \pm 0.07$ & $7.99 \pm 1.36$ & $17.38 \pm 0.66$ \\
\hline
\end{tabular}

From the results shown in Table 2, we can see that the lowest ash content was found in reed pellets (3.17\%). Comparing this figure with wood biofuel results, the ash content of the former is almost twice as high.

The moisture content of bulrush pellets reached $10.79 \%$ and was slightly higher than that of reed canary grass and reed; however, the results of all three plants fully met the requirements for granulated biofuel.

The calorific value of reed pellets reached $17.9 \mathrm{MJ} \mathrm{kg}^{-1}$. This calorific value is greater than that of willow (17.6 MJ kg-1 [7], but apprx. $2 \%$ lower than that of birch, which is the standard biofuel used in many countries.

For comparison, we present a study by Belgian scientists, investigating the properties of Bialobrzeskie, a kind of fibrous hemp [49]. The calorific value of Bialobrzeskie was $15.0-16.1 \mathrm{MJ} \mathrm{kg}^{-1}$; the determined ash content reached $1.5 \%-2.7 \%$. The ash deformation started when the temperature reached $710-850{ }^{\circ} \mathrm{C}$, whereas other melting temperatures exceeded $1500{ }^{\circ} \mathrm{C}[50]$. 
Other researchers have also studied the physical-mechanical properties of briquettes produced from fibrous hemp. The average density of these briquettes reached $1185 \mathrm{~kg} \mathrm{~m}^{-3} \mathrm{DM}$ (dry matter), and their breaking pressure varied from 101.3 to $122.4 \mathrm{~N} \mathrm{~mm}^{-1}$ [51].

\subsection{Pellet Mechanical Strength}

The results of pellet mechanical strength are presented in Figure 1. The maximum compression force of reed was the highest of all the plants under investigation and reached $549.2 \mathrm{~N}$. The maximum compression force of bulrush pellets was $543.2 \mathrm{~N}$ and that of reed canary grass pellets reached only $324.2 \mathrm{~N}$. Therefore, pellets made from these plants would be the least resistant to adverse effects during transportation, storage, or loading into a furnace of a boiler (Figure 1).

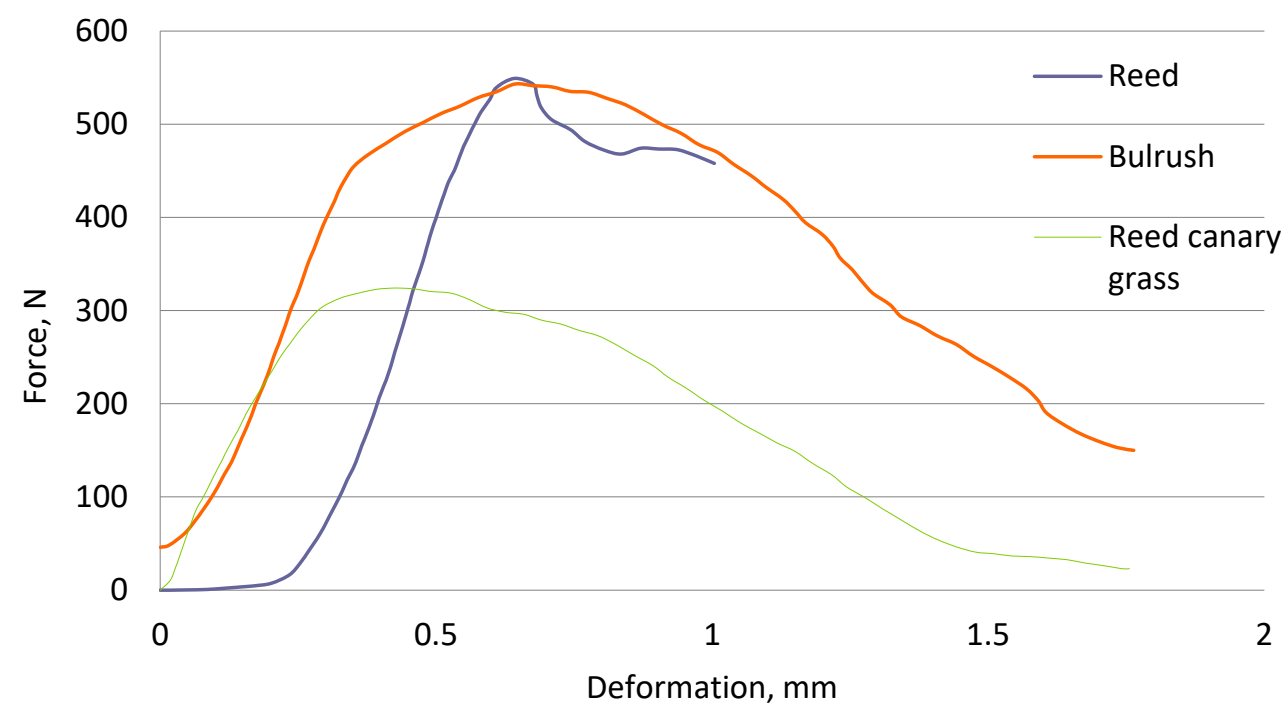

Figure 1. Pellet mechanical strength.

Latvian scientists investigated the strength of $36 \mathrm{~mm}$ diameter cylindrical briquettes [43]. The density of their investigated briquettes was of $1135 \mathrm{~kg} \mathrm{~m}^{-3}$ dry matter (this density was similar to that of our tested pellets), and critical breaking pressure varied from 99 to $115 \mathrm{~N} \mathrm{~mm}^{-1}$.

\subsection{Dependence of Pellet Density on Moisture Content}

The determined densities of reed, bulrush, and reed canary grass are presented in Figure 2. It may be observed that the higher the moisture, the lower the pellet density (Figure 2). The change of moisture content $(w)$ was proven to have a linear character (Equation (1)); it ranged from $5 \%$ to $15 \%$. The determined correlation coefficient varied from 0.644 to 0.989 .

$$
\rho=a w+b
$$

where:

$w$-pellet moisture content, $\%$;

$a$ and $b$-coefficients of the equation. 


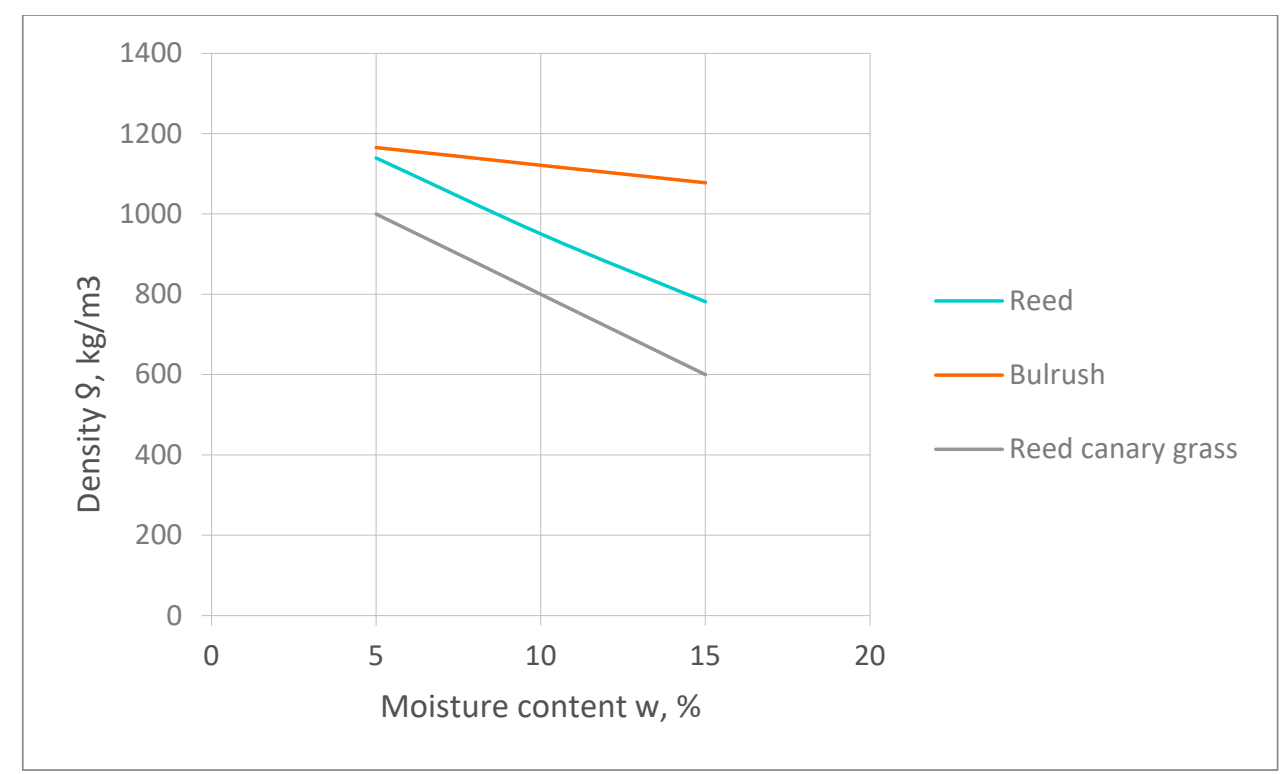

Figure 2. Density dependence on moisture.

\subsection{Dependence of Pellet Resistance to Compression on Moisture Content}

The dependence of reed, bulrush, and reed canary grass pellet compression resistance on moisture is shown in Figure 3. When moisture content increased, the compression resistance of the pellets declined in a linear character (Equation (2)). Moisture content (w) limits ranged from 5\% to 15\%. The determined correlation coefficient varied from 0.547 to 0.998 .

$$
F=a w+b
$$

where:

$w$-pellet moisture content, \%;

$a$ and $b$-coefficients of the equation.

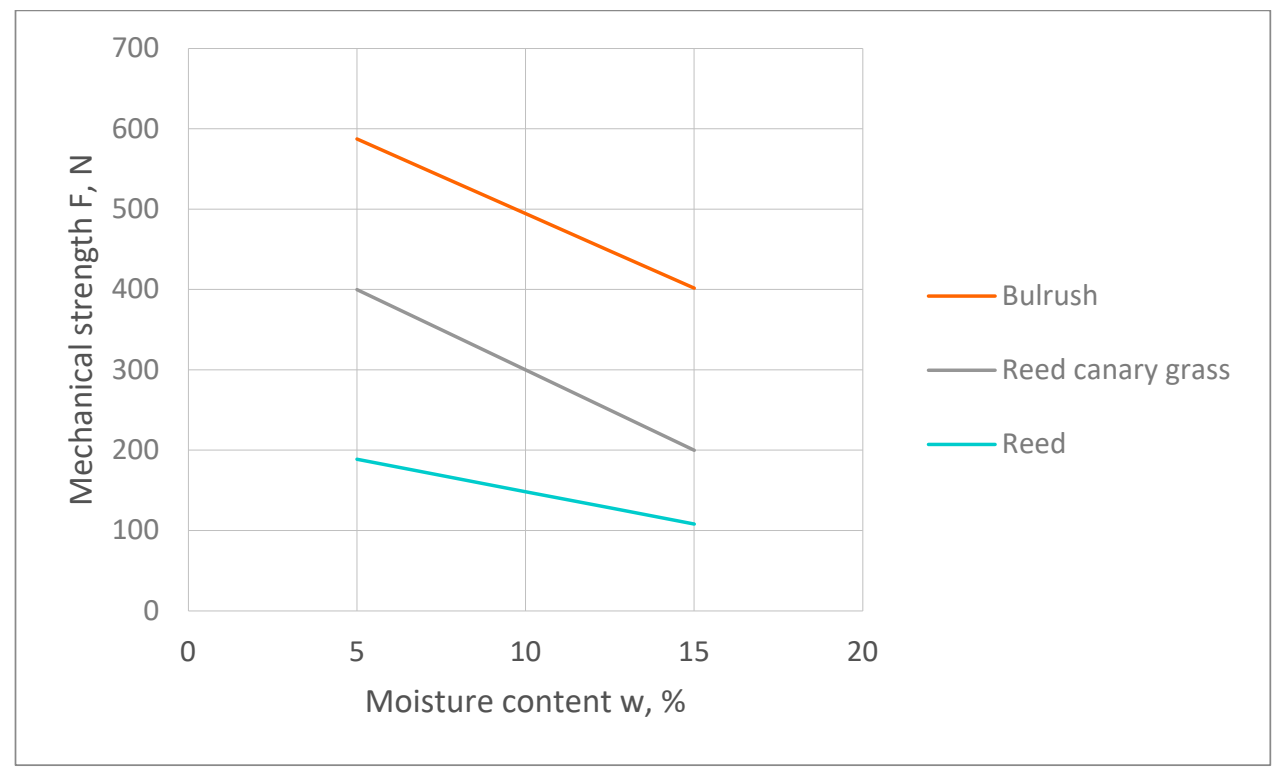

Figure 3. Dependence of pellet resistance to compression on moisture. 
Thus, many experimental studies of authors have been conducted on the most important properties of these unconventional plants, reeds, and pellets, which influence their preparation and burning. The physical-mechanical properties of the granules, which are significantly influenced by moisture content, such as granule density and compressive strength, were also evaluated, and their variations were a major determinant of pellet quality.

\subsection{Ash Melting Characteristics}

The melting characteristics of pellet ash are presented in Table 3.

Table 3. Ash melting temperatures.

\begin{tabular}{lcccc}
\hline \multirow{2}{*}{ Type of Biofuel } & \multicolumn{4}{c}{ Melting Characteristics, ${ }^{\circ} \mathbf{C}$} \\
\cline { 2 - 5 } & $\begin{array}{c}\text { Ash Softening } \\
\text { Temperature, ST }\end{array}$ & $\begin{array}{c}\text { Primary Ash } \\
\text { Deformation } \\
\text { Temperature, DT }\end{array}$ & $\begin{array}{c}\text { Ash Hemisphere } \\
\text { Temperature, HT }\end{array}$ & $\begin{array}{c}\text { Ash Fusibility } \\
\text { Temperature, FT }\end{array}$ \\
\hline Bulrush & $1216 \pm 8.49$ & $1411 \pm 7.07$ & $1498 \pm 11.31$ & $1500 \pm 11.31$ \\
Reed & $1139 \pm 9.90$ & $1349 \pm 4.24$ & $1444 \pm 9.90$ & $1458 \pm 7.07$ \\
Reed canary grass & $865 \pm 15.56$ & $1037 \pm 7.07$ & $1134 \pm 5.66$ & $1181 \pm 12.73$ \\
\hline
\end{tabular}

As determined, the smallest ash softening temperature (ST) was that of reed canary grass, $865^{\circ} \mathrm{C}$, and the highest one was that of bulrush, $1216^{\circ} \mathrm{C}$. The smallest primary ash deformation temperature (DT), in which the corners of the ash sample begin to round, was that of reed canary grass, $1037^{\circ} \mathrm{C}$, and the highest one was that of bulrush, $1411^{\circ} \mathrm{C}$. The softening temperature (ST) of reed ash was $1139^{\circ} \mathrm{C}$, the temperature of ash deformation (DT) reached $1349^{\circ} \mathrm{C}$.

The melting temperatures of plant ash have been studied by various scientists. For example, Poisha and Adamovich investigated and determined the melting temperatures of fibrous hemp ash, which ranged from 866 to $1150{ }^{\circ} \mathrm{C}$. The melting temperatures of reed canary grass ash, which were investigated by the Lithuanian scientists Čepauskienè and Pedišius, were higher and reached $1000-1270{ }^{\circ} \mathrm{C}[50,52]$. These melting temperatures were $7 \%-13 \%$ higher than the presented results of the authors, which was influenced by different plant species and their chemical composition.

\subsection{Emissions from Pellet Combustion}

Research results of investigated harmful gas emissions while burning reed, bulrush, and reed canary grass pellets are shown in Table 4. For comparison, the emissions of ashen wood are also presented in this table.

Table 4. Harmful gas emissions of reed plants.

\begin{tabular}{lcccc}
\hline \multirow{2}{*}{ Type of Biofuel } & \multicolumn{4}{c}{ Indicators of Gas Emissions } \\
\cline { 2 - 5 } & $\mathbf{C O}_{\mathbf{2}} \mathbf{\%}$ & $\mathbf{C O} \mathbf{~ p p m}$ & $\mathbf{N O}_{\mathbf{x}} \mathbf{p p m}$ & $\mathbf{C}_{\mathbf{x}} \mathbf{H}_{\mathbf{y}} \mathbf{p p m}$ \\
\hline Bulrush & 4.54 & 570 & 173.59 & 40.23 \\
Reed & 4.26 & 233.96 & 83.93 & 23.66 \\
Reed canary grass & 7.37 & 905.22 & 176.24 & 56.20 \\
Ashen wood & 4.94 & 360.50 & 46.30 & 34.28 \\
\hline
\end{tabular}

The pellets of all of these plants had similar $\mathrm{CO}_{2}$ emissions, except for reed canary grass, which emitted two times as much as the other plants. Nonetheless, none of the investigated plants exceeded the maximum permissible level of harmful emissions.

Another important aspect of the proximate analysis in terms of energetic value is that heating organic materials at high temperatures generates volatiles [53].

Scientists Malatak and Passian have also studied the properties and environmental impact of energy crop pellets during their combustion. Studies of harmful gas emissions of one unconventional 
herbaceous plant—giant knotweed-showed that carbon monoxide and nitric oxide concentrations were 929 and $297 \mathrm{mg} \mathrm{m}^{-3}$, respectively [54].

Polish scientists have evaluated hydrocarbons $\left(\mathrm{C}_{x} \mathrm{H}_{y}\right)$ of wood pellets; they ranged from 24 to 61 ppm [55]. Researchers from the USA and Poland have determined the $\mathrm{NO}_{x}$ concentration of wood biomass, which reached $170 \mathrm{mg} \mathrm{m}^{-3}$ [56].

According to other research, the determined $\mathrm{CO}$ concentration of wood pellets was significantly low and reached only $1.3 \mathrm{~g} \mathrm{~kg}^{-1}$. Similar studies have been carried out with peat pellets-the determined harmful CO emission was $140 \mathrm{mg} \mathrm{MJ}^{-1}$ and the $\mathrm{NO}_{\mathrm{x}}$ concentration was $225 \mathrm{mg} \mathrm{MJ}^{-1}[57,58]$.

Kortelainen et al. have studied the harmful emissions of wood and reed canary grass mixture pellets during burning. The results showed that $\mathrm{CO}$ concentration was $10 \mathrm{mg} \mathrm{MJ}^{-1}$ and NOx concentration reached $212 \mathrm{mg} \mathrm{MJ}^{-1}$ [59].

A study on giant knotweed briquettes determined that the concentration of $\mathrm{CO}$ was $3089.6 \mathrm{mg} \mathrm{m}^{-3}$, that of $\mathrm{NO}_{\mathrm{x}}$ was $195.0 \mathrm{mg} \mathrm{m}^{-3}$, and that of $\mathrm{HCl}$ was $157.69 \mathrm{mg} \mathrm{m}^{-3}$ [60].

The presented research results demonstrate that all investigated and determined pellet indicators meet high pellet quality requirements.

\subsection{Energy Evaluation and Assessment of GHG Emissions}

Energy evaluation.

The energy evaluation of granulated reed biofuel technology is shown in Table 5.

Table 5. The energy consumption of reed pellet production (yield of plant biomass $8.2 \mathrm{t} \mathrm{ha} \mathrm{a}^{-1}$, moisture content $25 \%$ ).

\begin{tabular}{|c|c|c|}
\hline \multirow{2}{*}{ Technological Operations } & \multicolumn{2}{|c|}{ Energy Consumption } \\
\hline & MJ ha-1 & MJ kg-1 \\
\hline \multicolumn{3}{|l|}{ Energy consumption of reed plant pellet production: } \\
\hline $\begin{array}{l}\text { Energy consumed for reed harvesting, loading into vehicle } \\
\text { trailers and transportation to storage facilities }\end{array}$ & 5740 & 0.7 \\
\hline Plant chopping & 2870 & 0.35 \\
\hline Milling and drying, in order to reduce moisture content by $10 \%$ & 16,400 & 2.0 \\
\hline Biomass pellet production in low power granulator & 1230 & 0.15 \\
\hline Pellet transportation and combustion equipment & 570 & 0.07 \\
\hline Total energy consumption: & 26,810 & 3.27 \\
\hline
\end{tabular}

The total energy consumption of granulated reed biofuel production, when the moisture content of the feedstock has been reduced by $10 \%$, was estimated to be $3.27 \mathrm{MJ} \mathrm{kg}^{-1}$. The determined lower calorific value of reed pellets was $17.86 \mathrm{MJ} \mathrm{kg}^{-1} \mathrm{DM}$ and boiler efficiency was 0.85 ; thus, the coefficient of energy efficiency $R$ is equaled $4.64(R=17.86 \times 0.85: 3.27=4.64)$. This means that granulated reed biofuel production requires 4.64 times less energy than the energy generated by burning this biofuel.

The results of the energy evaluation of reed pellet preparation for biofuel technology can be compared with the previously performed straw pellet energy evaluation technology. Similar results were obtained, since the calculated energy efficiency coefficient $R$ of the pelleted straw biofuel was equal to 3.5, i.e., about 1.3 times lower. Another important reason for promoting the use of reed plants for energy purposes is that these plants are remnants that need to be removed from the banks of rivers and lakes. Having in mind all of the above arguments, the biofuel made from reed plants can be defined as an environmentally-friendly biofuel, which minimally pollutes the atmosphere.

In summary, the results of the tests for reed plant pellet emissions during the burning show that investigated reed plants are suitable for burning by pressing them into pellets, but they may require additional energy consumption for mass drying and pelleting. Such usage of reed plant pellets for biofuel ensures a sufficiently high quality and an environmentally-friendly combustion process. 
Highly similar research results were obtained in other investigations in Lithuania and other European countries, utilizing different herbaceous and woody energy plants and their wastes for combustion.

Assessment of GHG emissions.

The determined greenhouse gas (GHG) emissions of the investigated reed plant pellet biofuel provided a complete picture of the product, i.e., where its environmental impact affected its entire life cycle, from biomass extraction to transportation, processing, and preparation of the final product-the pellets.

Research results showed that for $1 \mathrm{GJ}$ of energy from reed canary grass, the emitted amount of GHG was $10.1 \mathrm{~kg} \mathrm{CO}$-eq., while for $1 \mathrm{GJ}$ of energy from reed, the emitted amount of carbon dioxide was $7.3 \mathrm{~kg} \mathrm{CO}$-eq. (Figure 4). The results from other studies worth mentioning were as follows: giant knotweed-7.2 $\mathrm{kg} \mathrm{CO}_{2}$-eq. $\mathrm{GJ}^{-1}$ and nettle-10.3 $\mathrm{kg} \mathrm{CO}_{2}$-eq. GJ ${ }^{-1}$. Some researchers, such as Jolliet, Hamedani, and others, have also presented the methodology and research results of plant biomass life cycle assessment and environmental impact $[47,48]$.

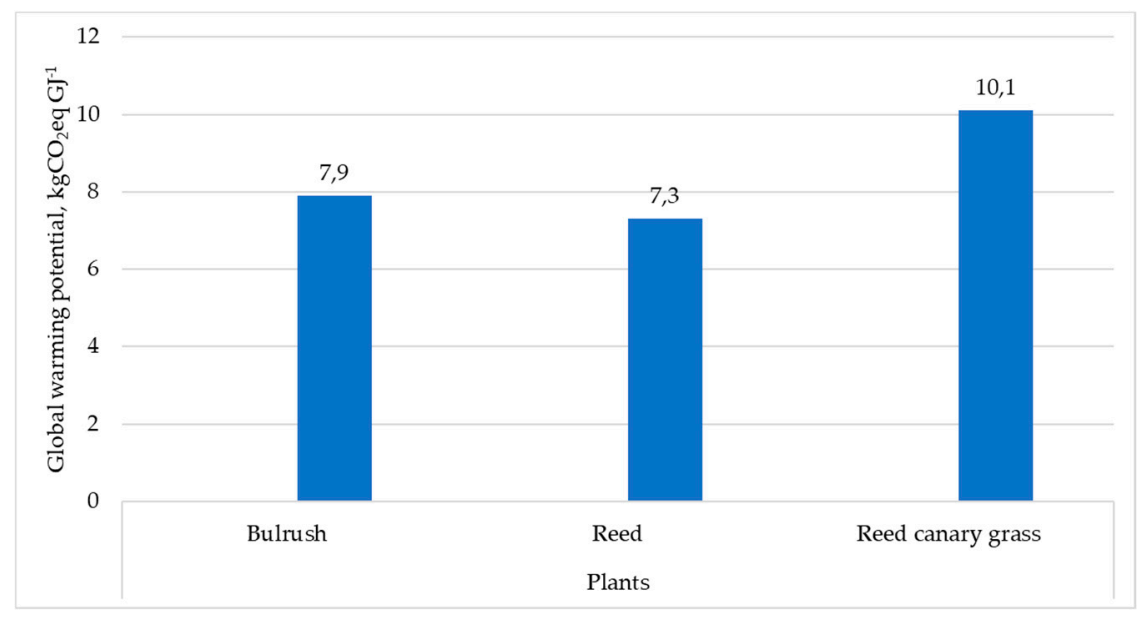

Figure 4. Global warming potential of reed plant pellets, including biomass extraction, transportation, processing, and final product preparation.

The results from [61] suggested that the emissions of greenhouse gases of the wood pellet production process consisted of only $6.5 \mathrm{~kg} \mathrm{CO}_{2}$-eq. $\mathrm{GJ}^{-1}$. Fantozzi and Buratti [62] detected that pelleting (with $61.2 \%$ of the overall impact) was the costliest process for the processing of plant biomass and production of granulated biofuels from the wood of poplar (Populus spp.). Their review [62] indicated that the production of wood pellets had the highest GHG emissions among other solid biofuel technologies.

\section{Conclusions}

The physical-mechanical, chemical, and thermal properties of granulated biofuel from three reed plant species (reed, bulrush, and reed canary grass) have been investigated and the impact on the environment during the burning of these biofuels has been analyzed.

The pellet density of the investigated reed plants has been analyzed and proven to be sufficient. The density exceeded the permissible requirements- $1000 \mathrm{~kg} \mathrm{~m}^{-3} \mathrm{DM}$ (dry matter), it reached the following values: for reed, $1178.9 \mathrm{~kg} \mathrm{~m}^{-3} \mathrm{DM}$, for bulrush, $1050.0 \mathrm{~kg} \mathrm{~m}^{-3} \mathrm{DM}$, and for reed canary grass, $1035.1 \mathrm{~kg} \mathrm{~m}^{-3} \mathrm{DM}$.

With regards to the elemental composition and the biofuel calorific value of the three investigated plant pellets, it is worth distinguishing the reed with a calorific value of $17.86 \pm 0.31 \mathrm{MJ} \mathrm{kg}^{-1}$, which was only $2 \%$ different from the conventionally treated birch.

The ash melting research revealed that bulrush had the highest ash ST (softening temperature) value, $1216 \pm 8.49^{\circ} \mathrm{C}$, compared to the other two plant pellets. The ST of reed was $1139 \pm 9.90^{\circ} \mathrm{C}$, and 
that of reed canary grass was very low- $865 \pm 15.56^{\circ} \mathrm{C}$. This indicated that the slag on the fire gate of the boiler would form faster; therefore, lower temperatures would be required.

The $\mathrm{CO}_{2}$ emissions during combustion were always similar, except for the reed canary grass pellets, which produced $7.37 \%$, almost two times the emissions of the other two plants. On the positive side, the harmful emissions of reed pellets can be specified as follows: $\mathrm{CO}_{2}-4.26 \%, \mathrm{CO}-233.96 \mathrm{ppm}$, $\mathrm{NO}_{\mathrm{x}}-83.93 \mathrm{ppm}$, and $\mathrm{C}_{\mathrm{x}} \mathrm{H}_{\mathrm{y}}-23.66 \mathrm{ppm}$.

The determined total energy consumption for the preparation and utilization for combustion of the granulated reed plant biofuel, after a $10 \%$ reduction in biomass moisture content, was $3.27 \mathrm{MJ} \mathrm{kg}^{-1}$, and the calculated energy efficiency coefficient was 4.64. The GHG emissions depended on the physical properties and yield of feedstock. The amounts of energy per land required to produce $1 \mathrm{GJ}$ of energy were different, resulting in GHG emissions of pellet production ranging from $7.3 \mathrm{~kg} \mathrm{CO}$-eq. $\mathrm{GJ}^{-1}$ (reed) to $10.1 \mathrm{~kg} \mathrm{CO}_{2}$-eq. $\mathrm{GJ}^{-1}$ (reed canary grass), while bulrush emitted $7.9 \mathrm{~kg} \mathrm{CO}_{2}$-eq. GJ ${ }^{-1}$.

After the investigation and determination of the most important properties of reed plants that can influence their preparation and use for energy, it has been determined that all of the analyzed reed plants could be used as biofuels because the pellets of these plants have met the standard requirements of high-quality biofuels. It could also be noted that reed and bulrush do not generally require planting and fertilization; their pellets can be made from wild-growing plants.

The novelty and originality of the presented work is such that many researchers have investigated, analyzed, and compared various types of biofuels and their individual properties, but they used a variety of different pressing and burning implements for biofuel production and energy conversion. The research presented here has been performed and the results presented in a complex manner, using certified measuring devices and combustion equipment, uniform for all plants. The relationship between different properties and the results of their comparative evaluations have been examined; additionally, theoretical dependences of pellet qualitative indices and life-cycle analyses were developed and presented.

Author Contributions: Conceptualization, A.J.; Methodology, A.J., D.S. and E.Š.; Software, K.V.; Validation, A.J., E.̌̌.; Formal Analysis, E.Š. and M.P.; Investigation, A.J. and D.S.; Resources, A.J. and E.Š.; Data Curation, A.J., D.S. and K.V.; Writing-Original Draft Preparation, D.S. and K.V.; Writing-Review \& Editing, A.J. and M.P.; Visualization, A.J. and M.P.; Supervision, M.P.; Project Administration, A.J.; Funding Acquisition, E.Š. and K.V. All authors have read and agreed to the published version of the manuscript.

Funding: This research received no external funding.

Conflicts of Interest: The authors declare no conflict of interest.

\section{References}

1. Maria, T.C.; Pantaleo, A.; Pellerano, A. Influence of process parameters and biomass characteristics on the durability of pellets from the pruning residues of Olea europea L. Biomass Bioenergy 2011, 35, 402-410. [CrossRef]

2. Sosa, L.L.; Jozami, E.; Oakley, L.J.; Montero, G.A.; Ferreras, L.A.; Venturi, G.; Feldman, S.R. Using C4 perennial rangeland grasses for bioenergy. Biomass Bioenergy 2019, 128, 1. [CrossRef]

3. Poddar, S.; Kamruzzaman, M.; Sujan, M.; Hossain, M.; Jamal, M.S.; Gafur, M.A.; Khanam, M. Effect of compression pressure on lignocellulosic biomass pellet to improve fuel properties: Higher heating value. Fuel 2014, 131, 43-48. [CrossRef]

4. Spath, P.L.; Mann, M.K. Coal versus biomass electricity generation-Comparing environmental implications using life cycle assessment. Natl. Renew. Energy Lab. 1997, 1-10.

5. Spot Crude Prices. Available online: https://www.bp.com (accessed on 28 February 2020).

6. Civitarese, V.; Acampora, A.; Sperandio, G.; Assirelli, A.; Picchio, R. Production of wood pellets from poplar trees managed as coppices with different harvesting cycles. Energies 2019, 12, 2973. [CrossRef]

7. Jasinskas, A.; Zvicevičius, E. Biomass Production Engineering: Textbook. Kaunas 2008, 100. (In Lithuanian) 
8. The Authors Used This Standard: DIN Plus Pellets or EN Plus Pellets. Available online: https://www. biopelletmachine.com/biopellet-making-guidance/wood-pellet-certification-standard.html (accessed on 28 February 2020).

9. Scholz, V.; Krüger, K.; Höhn, A. Environmentally Compatible and Energy-Efficient Production of Energy Plants. Agrartechnische 2001, 7, 63-71.

10. Kakitis, A.; Nulle, I.; Ancans, D. Mechanical properties of composite biomass briquettes. In Proceedings of the Environmental, Technology, Resources, Rezekne, Latvia, 20-22 June 2011. [CrossRef]

11. IPCC. Climate Change 2014 Mitigation of Climate Change: Working Group III Contribution to the Fifth Assessment Report of the Intergovermental Panel on Climate Change; Cambridge University Press: New York, NY, USA, 2014.

12. Muntean, M.; Guizzardi, D.; Schaaf, E.; Crippa, M.; Solazzo, E.; Olivier, J.G.J.; Vignati, E. Fossil $\mathrm{CO}_{2}$ Emissions of all World Countries-2018 Report, EUR 29433 EN; Publications Office of the European Union: Luxembourg, 2018. [CrossRef]

13. Sakalauskas, A. Substantiation of Plant Biomass (Straw, Grasses, Woody Plants, Etc.) Harvesting and Preparation of Biofuel Technologies; Final Report; Akademija: Kaunas Region, Lithuania, 2012; p. 108. (In Lithuanian)

14. Renewable Energy Statistics, January 2020. Available online: https://ec.europa.eu/eurostat/statisticsexplained/index.php/ (accessed on 20 January 2020).

15. Statistical Yearbook of Lithuania (2019 Edition). The Environment. Available online: https://osp.stat.gov.lt/ lietuvos-statistikos-metrastis/lsm-2019/aplinka-ir-energetika/energetika (accessed on 20 January 2020).

16. Verbickas, D.; Juknys, R.; Kleišmantas, A. The use of solid biofuels in Lithuania for heat production, future prospects and the impact on the environment. Energetika 2013, 59, 144. (In Lithuanian)

17. Lapinskas, R. Energy reception from biomass, development and perspectives: Conference. In Alternative Energy Resources Usage and Perspectives; Brussels, Belgium, 2010; p. 19.

18. Rice, B. Hemp as a feedstock for biomass-to-energy conversion. J. Ind. Hemp 2008, 13, 145-156. [CrossRef]

19. Vares, V.; Kask, U.; Muiste, P.; Pihu, T.; Soosaar, S. Biofuel user manual. Vilnius 2007, 168. (In Lithuanian)

20. Macak, M.; Nozdrovicky, L.; Hussein, A.O. Effect of preheating and different moisture content of input materials on durability of pellets made from different phytomass content. Acta Technol. Agric. 2015, 1, $22-27$. [CrossRef]

21. Hamedani, S.R.; Colantoni, A.; Galluci, F.; Salerno, M.; Silvestri, C.; Villerini, M. Comparative energy and environmental analysis of agro-pellet production from orchard woody biomass. Biomass Bioenergy 2019, 129, 1. [CrossRef]

22. Bai, A.; Popp, J.; Pető, K.; Szőke, I.; Harangi-Rákos, M.; Gabnai, Z. The Significance of Forests and Algae in CO2 Balance: A Hungarian Case Study. Sustainability 2017, 9, 857. [CrossRef]

23. Sterner, M.; Fritsche, U. Greenhouse gas balances and mitigation costs of 70 modern Germany-focused and 4 traditional biomass pathways including land-use change effects. Biomass Bioenergy 2011, 35, 4797-4814. [CrossRef]

24. Mitchell, C.; Bridgwater, A.; Stevens, D.; Toft, A.J.; Watters, M. Technoeconomic assessment of biomass to energy. Biomass Bioenergy 1995, 9, 205-226. [CrossRef]

25. Kurucz, E.; Fári, M.G.; Antal, G.; Gabnai, Z.; Popp, J.; Bai, A. Opportunities for the production and economics of Virginia fanpetals (Sida hermaphrodita). Renew. Sustain. Energy Rev. 2018, 90, 824-834. [CrossRef]

26. Borkowska, H.; Molas, R. Yield comparison of four lignocellulosic perennial energy crop species. Biomass Bioenergy 2013, 51, 145-153. [CrossRef]

27. Szepmlinski, W.; Parzonka, A.; Salek, T. Yield and energy efficiency of biomass production of some species of plants grown for biogas. Acta Sci. Pol. Agric. 2014, 13, 67-80.

28. Jagodzinska, K.; Czerep, M.; Kudlek, E.; Wnukowski, M.; Yang, W. Torrefaction of wheat-barley straw: Composition and toxicity of torrefaction condensates. Biomass Bioenergy 2019, 129, 1. [CrossRef]

29. Sulaiman, S.A.; Bamufleh, H.S.; Tamili, S.N.A.; Inayat, M.; Naz, M.Y. Characterization of date palm fronds as a fuel for energy production. Bull. Chem. Soc. Ethiop. 2016, 30, 465-472. [CrossRef]

30. Yin, C.Y. Prediction of higher heating values of biomass from proximate and ultimate analyses. Fuel 2011, 90, 1128-1132. [CrossRef]

31. Ren, T.; Enchen, J.; Yan, S.; Xiwei, X.; Shu, R. The Pelletization and Combustion Properties of Terrified Camelia Shell via Dry and Hydrothermal Torrefaction: A Comparative Evaluation. Bioresour. Technol. 2018, 264, 78-89. [CrossRef] 
32. Alvarez-Alvarez, P.; Pizarro, C.; Barrio-Anta, M.; Camara-Obregon, A.; Bueno, J.M.L.; Alvarez, A.; Gutierrez, I.; Burslem, D.F. Evaluation of tree species for biomass energy production in northwest Spain. Forests 2018, 9, 160. [CrossRef]

33. Obernberger, I.; Thek, G. Physical characterisation and chemical composition of densified biomass fuels with regard their combustion. Biomass Bioenergy 2004, 27, 653-669. [CrossRef]

34. IEA (International Energy Agency). World Energy Outlook 2014; OECD/IEA: Paris, France, 2014.

35. UNDP (United Nations Development Program). Word Energy Assessment: Energy and Challenge; UNPD: New York, NY, USA, 2002.

36. WEC (World Energy Council). Survey of Energy Resources 2010; Bioenergy WEC: Rome, Italy, 2010.

37. IPCC (Intergovernmental Panel on Climate Change). Climate Change 2007: Mitigation of Climate Change. In Contribution of Working Group III to the Fourth Assessment Report of the Intergovernmental Panel of Climate Change; Metz, B., Davidson, O.R., Bosch, P.R., Dave, R., Meyerleds, L.A., Eds.; Cambridge University Press: Cambridge, UK, 2007; p. 851.

38. IPCC (Intergovernmental Panel on Climate Change). Special Reports on Renewable Energy Sources. In Summary for Policy Makers, 11th Session of Working Group of the IPCC; IPCC: Abu Dhabi, UAE, 2011; pp. 5-8.

39. Jasinskas, A.; Streikus, D.; Vonžodas, T. Fibrous hemp (Felina 32, USO 31, Finola) and fibrous nettle processing and usage of pressed biofuel for energy purposes. Renew. Energy 2020, 149, 11-21. [CrossRef]

40. Reed. Available online: https://lt.wikipedia.org/wiki/Paprastoji_nendre (accessed on 13 June 2019).

41. Bulrush. Available online: https://lt.wikipedia.org/wiki/Švendras (accessed on 13 June 2019).

42. Reed Canary Grass. Available online: https://lt.wikipedia.org/wiki/Nendrinis_dryžutis\#/media/File:Phalaris_ arundinacea.jpeg (accessed on 13 June 2019).

43. Kadžiulienè, Ž.; Jasinskas, A.; Zinkevičius, R.; Makarevičienè, V.; Šarūnaitè, L.; Tilvikienè, V.; Šlepetys, J. Miscanthus biomass quality composition and methods of feedstock preparation for conversion into synthetic diesel fuel. Zemdirb. Agric. 2014, 101, 27. [CrossRef]

44. Djatkov, D.; Viskovic, M.; Golub, M.; Martinov, M. Corn cob pellets as a fuel in Serbia: Opportunities and constraints. In Symposium Actual Tasks on Agricultural Engineering; University of Zagreb, Faculty of Agriculture: Opatija, Croatia, 2017.

45. Šiaudinis, G.; Jasinskas, A.; Šarauskis, E.; Steponavičius, D.; Karčiauskienè, D.; Liaudanskienè, I. The assessment of Virginia mallow (SidahermaphroditaRusby) and cup plant (Silphiumperfoliatum, L.) productivity, physico-mechanical properties and energy expenses. Energy 2015, 93, 606. [CrossRef]

46. CEN/TC 14774-1:2005. Solid Biofuels-Methods for the Determination of Moisture Content-Oven Dry Method_Part 1: Total Moisture_Reference Method; British Standards Institution: London, UK, 2005.

47. Jolliet, O.; Margni, M.; Charles, R.; Humbert, S.; Payet, J.; Rebitzer, G.; Rosenbaum, R. IMPACT 2002+: A new life cycle impact assessment methodology. Int. J. LCA 2003, 6, 324-330. [CrossRef]

48. Hamedani, S.; Kuppens, T.; Malina, R.; Bocci, E.; Colantoni, A.; Villarini, M. Life cycle assessment and environmental evaluation of biochar production: Two case studies in Belgium. Energies 2019, 12, 2166. [CrossRef]

49. UCTE: Resources. Available online: https://www.ucte.org/resources/dataportal/statistics/exchange (accessed on 17 December 2019).

50. Poisa, L.; Adamovics, A. Evaluate of hemp (Cannabis sativa L.) quality parameters for bioenergy production. In Proceedings of the Engineering for Rural Development, Jelgava, Latvia, 26-27 May 2011; pp. 358-362.

51. Kakitis, A.; Nulle, I.; Ancans, D. Mechanical properties of energy crops. In Proceedings of the Engineering for Rural Development, Jelgava, Latvia, 26-27 May 2011; pp. 440-445.

52. Čepauskienè, D.; Pedušius, N. Investigation of the Effect of Kaolin Additive and Different Ashing Temperatures of Agromass; CYSENI: Kaunas, Lithuania, 2018; pp. 35-39.

53. Garcia, R.; Pizaro, C.; Lavin, A.G.; Bueno, J.J. Characterization of Spanish biomass wastes for energy use. Bioresour. Technol. 2012, 103, 249-258. [CrossRef]

54. Malatak, J.; Passian, L. Heat-emission analysis of small combustion equipments for biomass. Res. Agric. Eng. 2011, 57, 37-50. [CrossRef]

55. Szyslak-Barglowicz, J.; Zajac, G.; Slowik, T. Hydrocarbon emissions during biomass combustion. Pol. J. Environ. Stud. 2015, 24, 1349. [CrossRef] 
56. Higgins, B.; Yan, L.; Gadalla, H.; Meier, J.; Fareid, T.; Liu, G.; Milewicz, M.; Repczynski, A.; Ryding, M.; Blasiak, W. Biomass co-firing retrofit with ROFA for NOx reduction. Pol. J. Environ. Stud. 2010, 19, 1185. [CrossRef]

57. Krugly, E.; Martuzevicius, D.; Puida, E.; Buinevicius, K.; Stasiulaitiene, I.; Radziuniene, I.; Minikauskas, A.; Kliucininkas, L. Characterization of gaseous- and particle-phase emissions from the combustion of biomass-residue-derived fuels in a small residential boiler. Energy Fuels 2014, 28, 5057. [CrossRef]

58. Sippula, O.; Lamberg, H.; Leskinen, J.; Tissari, J.; Jokiniemi, J. Emissions and ash behavior in a $500 \mathrm{~kW}$ pellet boiler operated with various blends of woody biomass and peat. Fuel 2017, 202, 144. [CrossRef]

59. Kortelainen, M.; Jokiniemi, J.; Nuutinen, I.; Torvela, T.; Lamberg, H.; Karhunen, T.; Tissari, J.; Sippula, O. Ash behaviour and emission formation in a small-scale reciprocatinggrate combustion reactor operated with wood chips, reed canary grass and barley straw. Fuel 2015, 143, 80. [CrossRef]

60. Strašil, Z.; Kara, J. Study of knotweed (Reynoutria) as possible phytomass resource for energy and industrial utilization. Res. Agric. Eng. 2010, 56, 161. [CrossRef]

61. Adams, P.W.R.; Shirley, J.E.J.; McManus, M.C. Comparative cradle-to-gate life cycle assessment of wood pellet production with torrefaction. Appl. Energy 2015, 138, 367-380. [CrossRef]

62. Fantozzi, F.; Buratti, C. Life cycle assessment of biomass chains: Wood pellet from short rotation coppice using data measured on a real plant. Biomass Bioenergy 2010, 34, 1796-1804. [CrossRef]

(C) 2020 by the authors. Licensee MDPI, Basel, Switzerland. This article is an open access article distributed under the terms and conditions of the Creative Commons Attribution (CC BY) license (http://creativecommons.org/licenses/by/4.0/). 